\title{
ELECTRIC FISH BARRIER FOR PROTECTING SMALL CARPS IN EĞIRDIR LAKE
}

\author{
Talat Yalçınkaya, Abdülkadir Çakır, Yıldız Bolat, Rahmi Uysal, Ali Aslantas
}

Original scientific paper

Juvenile fishes which have economic value in Eğirdir Lake, the fourth largest lake in Turkey according to its size, are killed due to electric water pumps used for the purpose of irrigation and drinking water. In this study, an electric fish barrier was designed to keep fish away from withdrawal points of electric water pumps. Results were tested in laboratory conditions. Each experiment was performed in triplicate using 30 fish (that is, the total number of fish used for each experiment was 90). Analysis of variance (ANOVA) was used to evaluate the results by using SPSS program. The experimental results demonstrated that the $50 \mathrm{~V} / 10 \mathrm{~Hz}$ value cannot be used because of the adverse effects. $20 \mathrm{~V} / 10 \mathrm{~Hz}$ and $35 \mathrm{~V} / 10 \mathrm{~Hz}$ values are suitable to keep fish away from the barriers.

Keywords: electric field; fish barrier; fish directing; fish repellent; microcontroller

Električna barijera za zaštitu malih šarana u jezeru Eğirdir

Izvorni znanstveni članak

Sitna riba od ekonomske vrijednosti u jezeru Eğirdir, četvrtom po veličini u Turskoj, ubija se električnim vodenim pumpama koje se koriste za navodnjavanje i vodu za piće. U ovom je radu konstruirana električna barijera koja ribu drži dalje od crpilišta električnih vodenih pumpi. Rezultati su provjeravani u laboratorijskim uvjetima. Svaki je eksperiment ponovljen tri puta s 30 riba (odnosno, ukupan broj riba za svaki eksperiment bio je 90). Rezultati su se provjeravali analizom varijance (ANOVA) uz primjenu SPSS programa. Eksperimentalni rezultati su pokazali da se vrijednost 50 V/10 Hz ne može koristiti zbog negativnih učinaka. Kao barijera za ribu odgovarajuće vrijednosti su 20 V/10 Hz i $35 \mathrm{~V} / 10 \mathrm{~Hz}$.

Ključne riječi: barijera za ribu; električno polje; mikrokontroler; odbojnik ribe; usmjeravanje ribe

\section{Introduction}

Fish barrier systems are divided into physical and non-physical barriers. Physical fish barriers are not preferred because they affect water flow and have high maintenance costs, whereas non-physical barriers are preferred due to their longevity and low maintenance costs. Non-physical barriers consist of mechanisms such as bubbles, electrical, lighting, acoustics, and a diverse mix of barrier systems. Electric barrier systems are more efficient than other non-physical barriers.

Physicist Konrad Kreutzer, who discovered the electric fish network, found that if $0.5 \mathrm{~V}$ and $1.5 \mathrm{~V}$ are applied to the tail and head portion of commercial fish species, electro-narcosis (that is, a "swoon state") is caused in fish. At the same time, Kreutzer was able to demonstrate that a higher value for voltage caused the deaths of the fish in his experiments [1]. Smith experimented to remove sharks from the beach with the use of electricity and concluded that a minimum of $6 \mathrm{~V} / \mathrm{m}$ and 16 units of $0.8 \mathrm{~ms}$ sine pulse per second was needed to have an effect on a brown shark of $0.75 \mathrm{~m}$ length (Carcharhinus obscurus) [2]. Kolz and Johnson developed electroshock devices to keep beavers, ducks, and geese away from a certain area. The process of holding outside from the area was carried out successfully without damaging the ducks, geese, and beaver [3]. Mcinerney and colleagues reviewed their creation of the electric fish barrier in the Chicago Sanitary and Ship Canal, which was intended to prevent passage of unwanted species that are harmful to other species such as Asian carp. It has been observed in experimental studies that fish returned to their point of origin (that is, gone back where they were) after failing to pass the barrier [4]. Lambooij and colleagues assessed the loss of sensitivity and awareness in a group of African catfish after they were administered electric shocks and placed in ice water, in an attempt to measure the potential impact of an electrical fish barrier. In this study, $88 \%$ of the catfish (at a confidence interval of $95 \%$ ) were adequately stunned to prevent breaking of an electrical fish barrier [5]. Huveneers and colleagues investigated the behaviour of the white shark with the use of the "Shark Shield Freedom 7" device for personal protective equipment designed to protect against attacks from shark. Shark Shield Freedom 7 was found to affect the behaviour of white sharks, but in each case the repelling effects were inadequate in deterring sharks from making multiple attempts to cross the barrier [6]. Erikson and colleagues used electric current to stun Atlantic codfish grown in farms before processing. Results showed that the fish would be killed if they remained exposed to the same power level for longer than 15 seconds [7]. Franssen and colleagues were partially successful in their use of electric fish capture methods in the San Juan River, New Mexico, and Utah to reduce (or eliminate) the density of the non-native species of fish [8]. Parker and colleagues examined the efficiency of the electric barrier system implemented in the Chicago Sanitary and Ship Canal on some fish species by increasing electrical output value; the results showed that the barrier worked [9].

One of the focal points of research today is the impact of electricity on fish. Electricity is used for purposes including catching, redirecting and stunning fish. The water is being pulled from Eğirdir Lake, the fourth largest in Turkey, with the pumps used for the purposes of extracting water for irrigation and drinking. Water flows towards the pump during the withdrawal of water. The water pumps draw in fish close to this stream, the results being injuries to the fish and pump damage. To prevent withdrawal of economically important fish fry and the use of fish fry solely to feed carnivorous fish drawn by the pumps during water withdrawal from Eğirdir Lake, an electric fish barrier is designed and tested in laboratory conditions. The advantage of designed system is low-cost 
and easy to install when compared with other similar systems.

\section{Material and methods}

An electric fish barrier is formed by passing current in the water. To apply the electric voltage, 2 or more electrodes are submerged into the water as shown in Fig. 1. Fish remaining in the electric field become a part of the electrical circuit and the current passes through their bodies. The shock level of the fish may result in paralysis, death, or light tripping depending on the value and duration of the electric current [10].

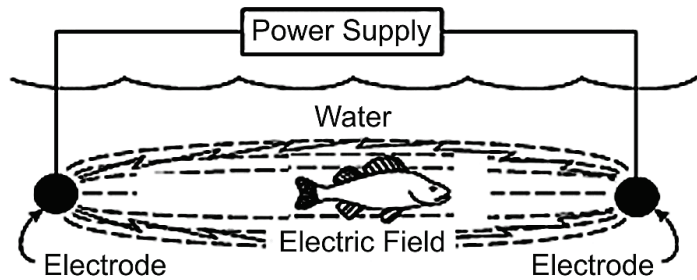

Figure 1 Electrical field generated in the water [10]

Three different situations that require evaluation exist in the electric field. These are the following: the conductivity of fish $\left(\sigma_{\mathrm{b}}\right)$ is greater (fresh water) or smaller (sea water) than the water's conductivity $\left(\sigma_{\mathrm{s}}\right)$, or is the same as the water's conductivity. This can be seen in Fig. 2. The vertical lines in Fig. 2 represent voltage; the horizontal lines represent current. The third state, in which the conductivity of the fish is equal to the conductivity of the water, is the best of the 3 states with respect to conductivity [11].

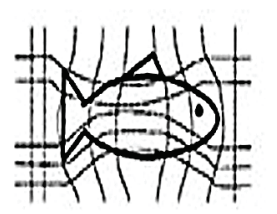

$\sigma_{\mathrm{b}}>\sigma_{\mathrm{s}}$

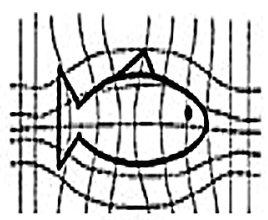

$\sigma_{\mathrm{b}}<\sigma_{\mathrm{s}}$

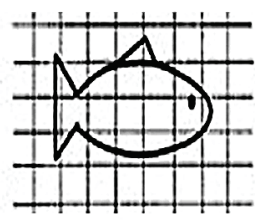

$\sigma_{\mathrm{b}}=\sigma_{\mathrm{s}}$
Figure 2 Condition of the fish in the electrical field [11]

In electric fish barrier systems, the desired characteristic is that the electric field has an influence from head to tail, as shown in Fig. 3. Thus, maximum power is administered to the fish in the water. The lines indicated by the broken arrows in Fig. 3 show the electric field and direction. Both alternating current (AC) and direct current (DC) may be used in an electric barrier. But it is well known that AC causes stress on the fish. AC is three times more dangerous than DC [10]. DC was preferred as current owing to safety reasons mentioned above.

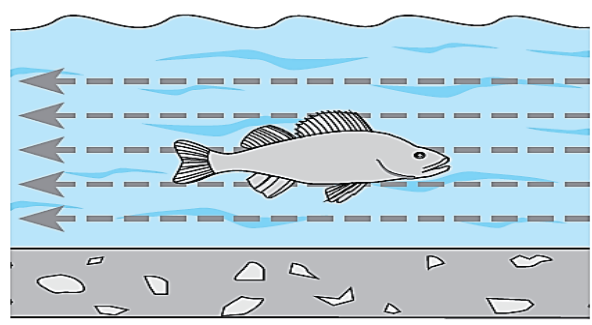

Figure 3 The electric field present in fish [10]

The electric barrier system in this study consists of four main components. As shown in Fig. 4 these are (1) power supply, (2) on/off time control, (3) switching times, and (4) description of the water tank.

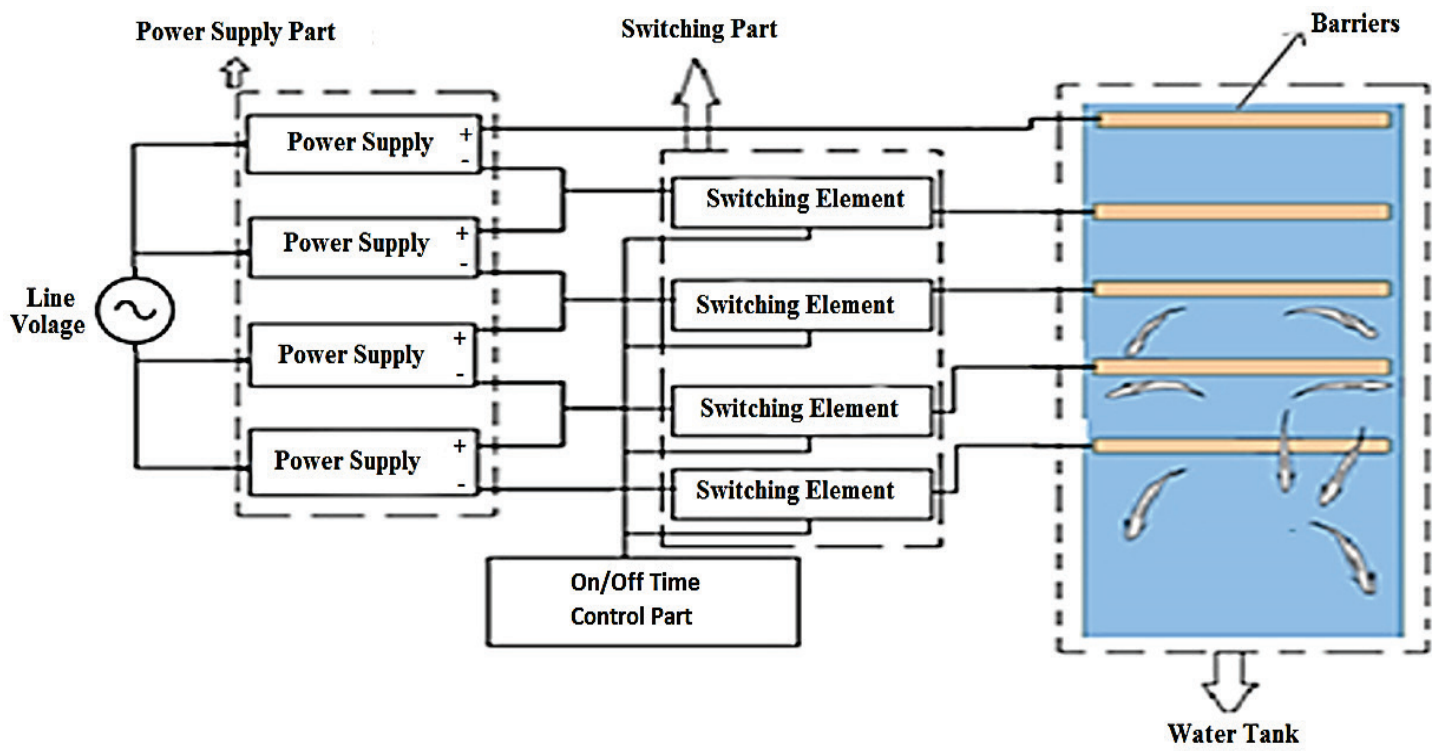

Figure 4 Electric fish barrier system

\subsection{Power supply}

The DA buck converted power supply created was adjustable between $1.2 \mathrm{~V}$ and $50 \mathrm{~V}$, switch-capable and had 3 A output. This type of power supply is preferred because it includes a small number of circuit elements and is lightweight, of small size and low cost. The power supply circuit used in the study is shown in Fig. 5.

$$
V_{\text {Out }}=V_{\text {Ref }} \cdot\left(1+\frac{R_{2}}{R_{1}}\right) \text {. }
$$

In Eq. (1), $V_{\text {Out }}$ represents the output voltage, $V_{\text {Ref }}$ represents the reference voltage, and $R_{1}$ and $R_{2}$ are the resistors setting the output voltage. 


$$
R_{2}=R_{1} \cdot\left(\frac{V_{\text {Out }}}{V_{\text {Ref }}}-1\right) .
$$

$V_{\text {Ref }}=1.23 \mathrm{~V}$ and the $R_{1}$ value should be between $5 \mathrm{k} \Omega$ and $1 \mathrm{k} \Omega$, Eq. (2).

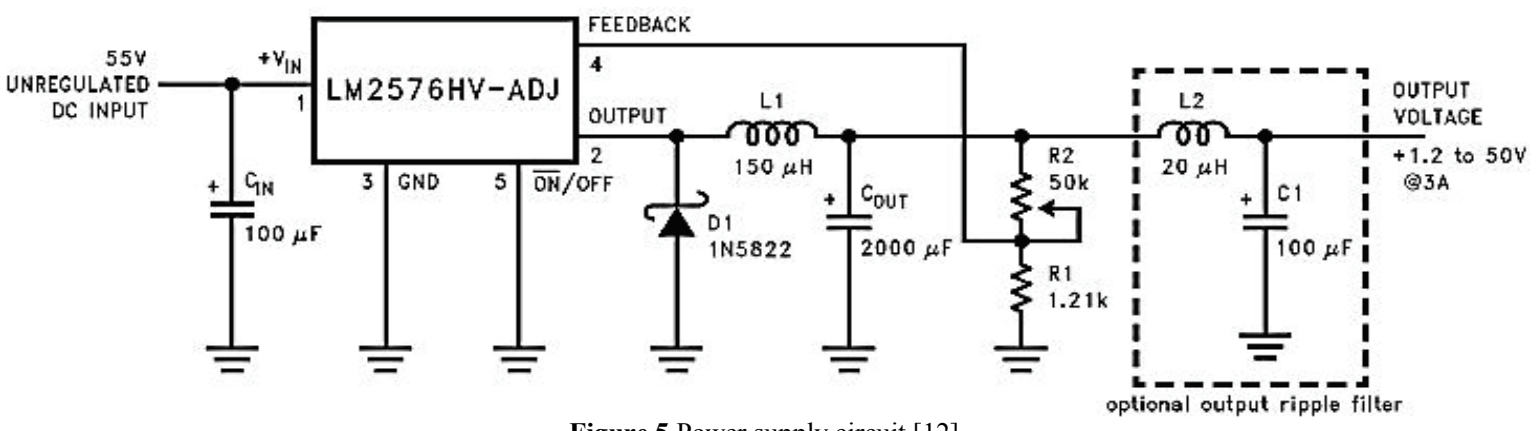

Figure 5 Power supply circuit [12]

\subsection{On/off time control}

On/off time control was carried out by producing PWM signal. The PWM is a signal produced at a precise moment and for an exact period of time [13]. PIC16F628A microcontroller is used as a device. Open circuit diagram of on/off control is given in Fig. 6. This circuit produces $5 \mathrm{~V}$ square wave and determines cut-off and transmission time of MOSFETs in the switching section. The panel shown in Fig. 7 was used to control "on" and "off" time of the applied voltage. The square wave on and off times can be changed independently from $1 \mathrm{~ms}$ to $1000 \mathrm{~ms}$ of each other. The time is shown on the LCD screen in milliseconds. Time can be reduced or its increments adjusted in multiples of one, ten, and done hundred.

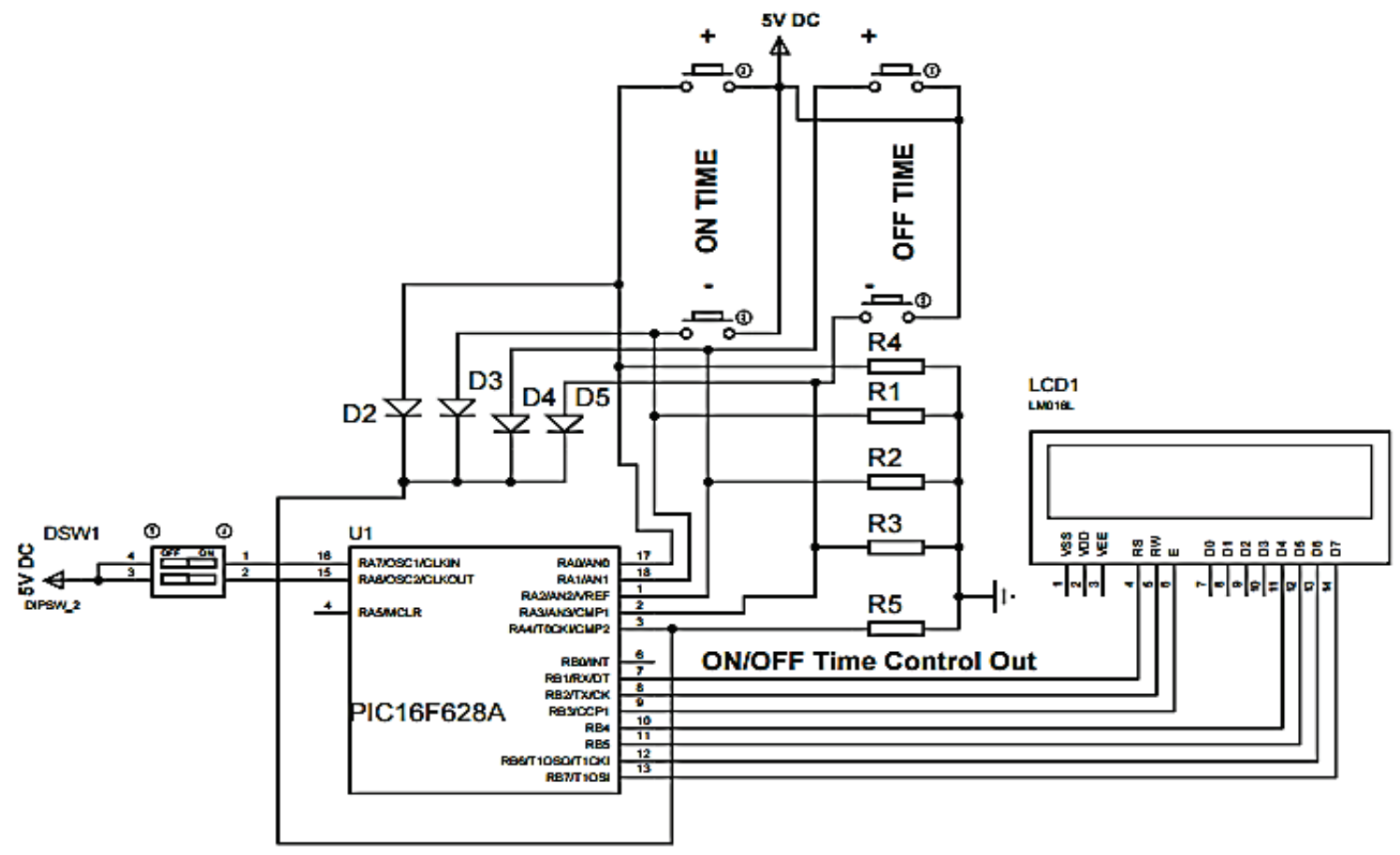

Figure 6 ON/OFF time control circuit

System immediately cuts off the current at the moment of danger by pressing the stop button on the panel.

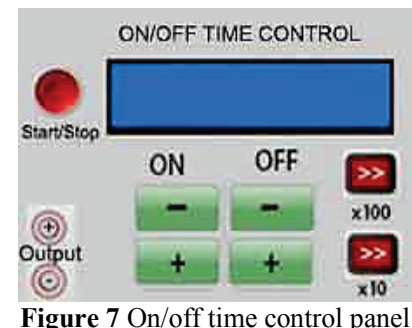

Figure 7 On/off time control pane

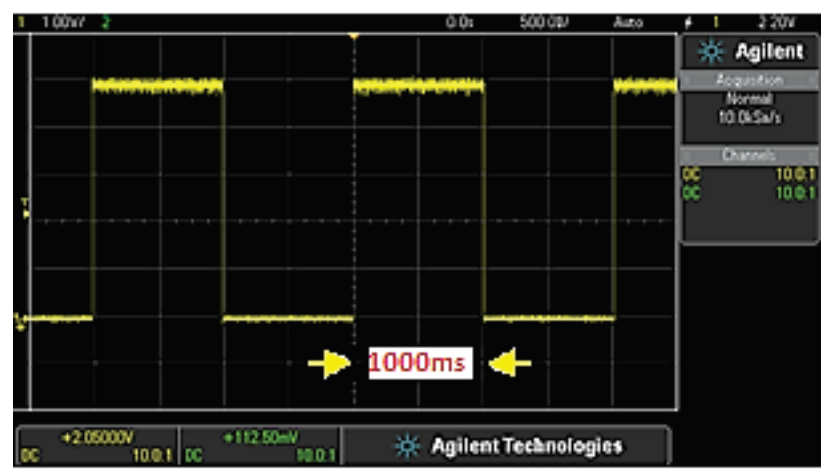

Figure 8 Obtained oscilloscope values at maximum values 
Fig. 8 and Fig. 9 show the oscilloscope image obtained at the minimum and maximum values of the unit.

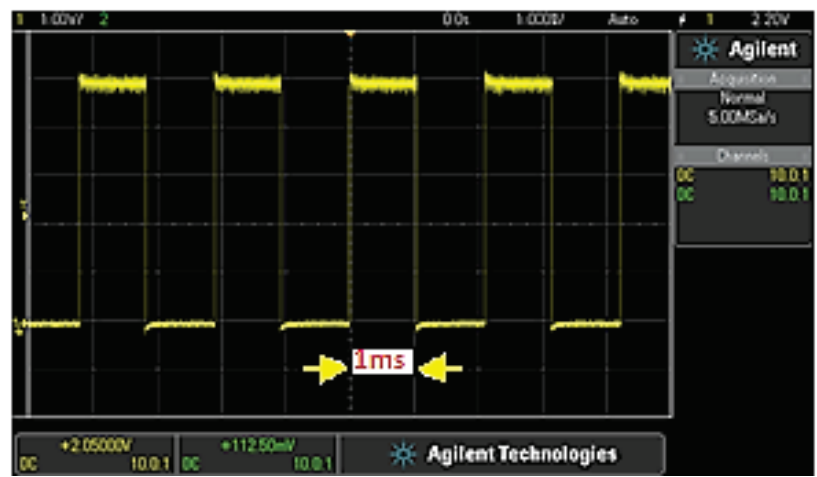

Figure 9 Obtained oscilloscope values at minimum values

\subsection{Switching times}

To apply DC to the barrier in the form of a square wave, a switching circuit was designed which can be seen in Fig. 10. The designed switching circuit was used in this system four times.

Metal-oxide-conductor field-effect transistor (MOSFET) is preferred as the switching element in this circuit due to its high input impedance, its ability to operate at high frequencies, low power consumption, and better mechanical strength. IR2117 single channel driver is used as an integrated MOSFET driver.

On/off times of the square waveform to be applied to the barrier were transmitted through the MOSFET driver and integrated through a 4N25 opto isolator. The voltage needed for IR2117 is provided by an L7815 voltage regulator.

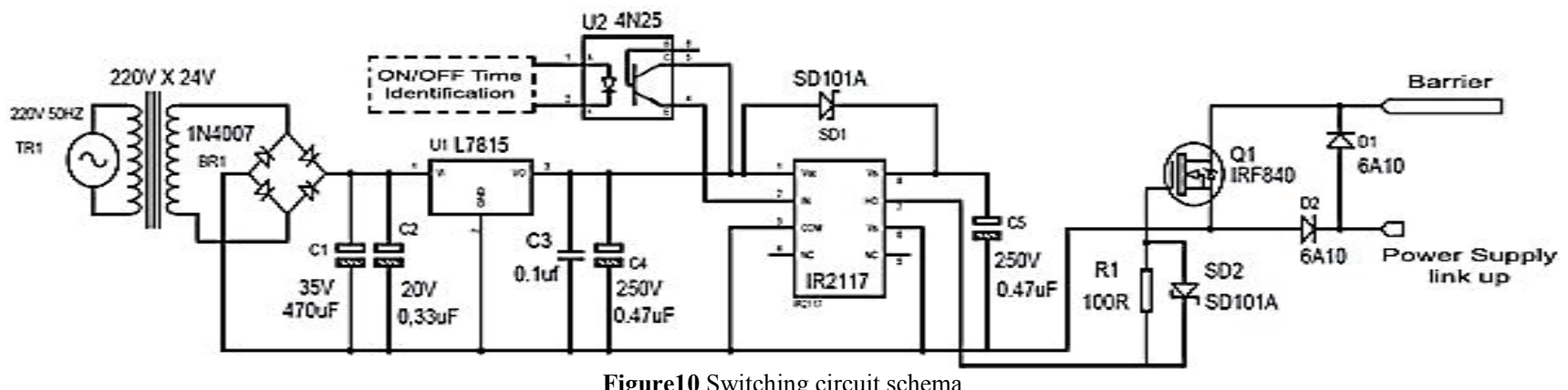

Fig. 11 shows the reason for using diodes D1 and D2 in Fig. 10; namely, these diodes will allow the current direction flowing through the MOSFET to constantly pass in the drain-source direction. When MOSFET(Q1) is in transmission, the $I_{1}$ current completes the circuit over D2 and MOSFET. $I_{2}$ will flow through the load passing through diode D1 without passing through Q1. When all MOSFET are not on transmission, energy won't be implemented through the loads.

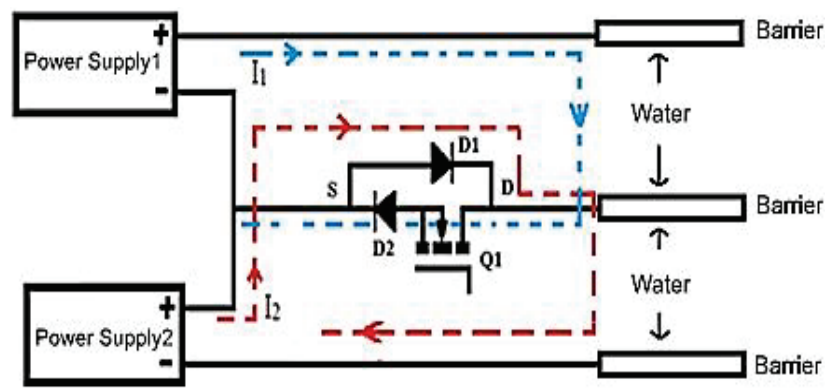

Figure 11 The current and its directions passing through on the MOSFET

Each MOSFET group in the switching section was fed from different sources. If all of the MOSFETs were to be fed from a single source, the source terminals connected with the chassis would short circuit, causing a short circuit of the other barriers except the first barrier and the power supply output. To avoid this event, each of the four switching elements in the switching section has been fed from different sources.

\subsection{Water tank}

Fig. 12 shows the $60 \times 300 \times 15.5 \mathrm{~cm}$ fiberglass water tank used in this study. As water is poured from a certain height to the tank, fish want to go to the other side of the tank, passing through the barriers. The water used is in a continuous stream, with a conductivity of $548 \mathrm{~S} / \mathrm{cm}$ and temperature of $12.9{ }^{\circ} \mathrm{C}$. 5 pieces of $0.8 \mathrm{~mm}$ thick copper wire used as a barrier is placed to the floor of the tank at $20 \mathrm{~cm}$ intervals without allowing fish to pass under the barrier.

The height of the water above the barrier was kept constant at $13.5 \mathrm{~cm}$, which is the minimum level required for the fish used in the experiment. Barrier position and water height above the barrier are the parameters that determine the voltage fishes will be exposed to in water. Fish were monitored remotely via webcam, as the human factor (that is, the clear presence of humans on-site) can influence the behaviour of fish.

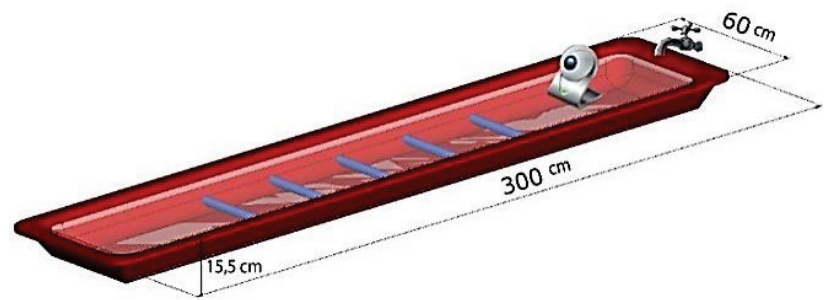

Figure 12 Water tank

\section{Results}

$20 \mathrm{~V}, 35 \mathrm{~V}$, and $50 \mathrm{~V}$ square waves were applied to the portions of the barrier with an occupancy rate of $50 \%$ 
(equal on and off times) as $10 \mathrm{~Hz}, 2.5 \mathrm{~Hz}$, and $1.25 \mathrm{~Hz}$, respectively. These values were randomly selected. Each experiment was repeated three times for 5 minutes. 30 carp fry were used for each of the experiments (for a total of 90 carp fry). By providing these conditions, the amount of current passing through the barrier, the voltage applied to the barrier, and the frequency and the number of fish in the barrier is shown in Tab. 1, and as a chart in Fig. 13.

Fig. 13 shows that if applied voltage and frequency values increase, the number of fish passing through the barrier decreases. No fish passed through the barrier in the experiment performed at $50 \mathrm{~V} / 10 \mathrm{~Hz}$. Fish trying to pass through are discouraged (impeded) by the value of the voltage and the frequency. Fig. 14 shows the images for the active and passive position of the barrier.

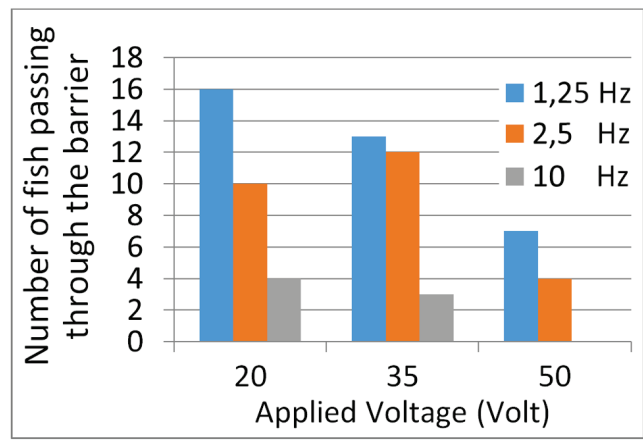

Figure 13 The number of fish passing through the barrier, frequency, and voltage values

Table 1 Number of fish passing through the barrier and electrical values

\begin{tabular}{|c|c|c|c|c|c|c|c|c|c|c|}
\hline \multirow[t]{2}{*}{ Test Sequence } & \multirow{2}{*}{$\begin{array}{l}\text { Voltage } \\
\text { (V) }\end{array}$} & \multicolumn{5}{|c|}{ Highest electrical current at barriers (Ampere) } & \multirow{2}{*}{$\begin{array}{l}\text { Frequency } \\
\quad(\mathrm{Hz})\end{array}$} & \multicolumn{3}{|c|}{$\begin{array}{c}\text { Number of fish passing through } \\
\text { the barrier }\end{array}$} \\
\hline & & 1. Barrier & 2. Barrier & 3. Barrier & 4. Barrier & 5. Barrier & & 1. Repeat & 2. Repeat & 3. Repeat \\
\hline 1. Experiment & 20 & 0.089 & 0.02 & 0.01 & 0.018 & 0.092 & 10 & 2 & 1 & 1 \\
\hline 2. Experiment & 20 & 0.16 & 0.029 & 0.03 & 0.029 & 0.16 & 2.5 & 5 & 3 & 2 \\
\hline 3. Experiment & 20 & 0.15 & 0.037 & 0.05 & 0.034 & 0.15 & 1.25 & 5 & 5 & 6 \\
\hline 4. Experiment & 35 & 0.161 & 0.04 & 0.001 & 0.038 & 0.162 & 10 & 2 & 0 & 1 \\
\hline 5. Experiment & 35 & 0.295 & 0.068 & 0.002 & 0.067 & 0.28 & 2.5 & 4 & 6 & 2 \\
\hline 6. Experiment & 35 & 0.302 & 0.075 & 0.006 & 0.078 & 0.304 & 1.25 & 4 & 6 & 3 \\
\hline 7. Experiment & 50 & 0.235 & 0.057 & 0.005 & 0.058 & 0.241 & 10 & 0 & 0 & 0 \\
\hline 8. Experiment & 50 & 0.445 & 0.102 & 0.009 & 0.105 & 0.449 & 2.5 & 2 & 1 & 1 \\
\hline 9. Experiment & 50 & 0.426 & 0.104 & 0.008 & 0.098 & 0.414 & 1.25 & 3 & 2 & 2 \\
\hline
\end{tabular}

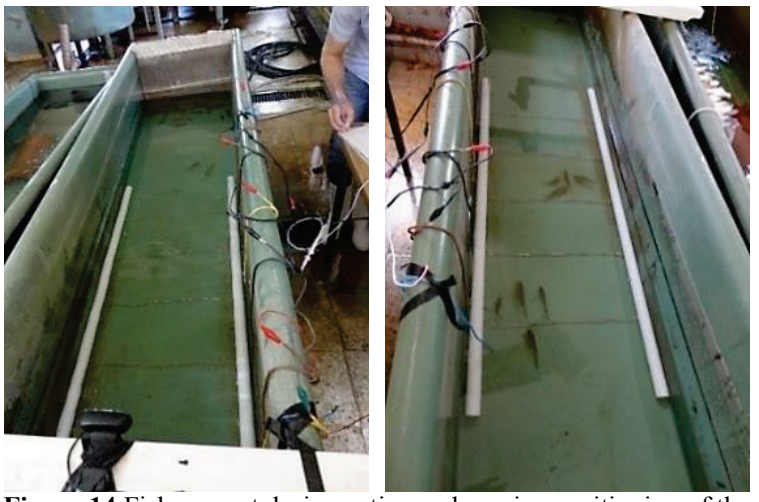

Figure 14 Fish present during active and passive positioning of the barrier

In this study, in order to determine the harmless proper voltage and frequency values for fishes, data were examined using an analysis of variance (ANOVA) statistical method by using SPSS program.

During the first, second and third experiment groups, in which $20 \mathrm{~V}$ was applied, a significant difference existed among the test groups $[F(2-6)=12,000, p<0.01]$. To find the source of significant difference, a Tukey honest significant difference (HSD) test was performed. The findings of the experiment performed at $20 \mathrm{~V} / 10 \mathrm{~Hz}$ ) showed that this is suitable for an electric fish barrier system.

The fourth, fifth and sixth experiment groups, in which $35 \mathrm{~V} / 2.5 \mathrm{~Hz}$ was applied, showed an insignificant between-group difference $(p>0.01)$ between test groups at $35 \mathrm{~V}[F(2-6)=2,515, p>0.01]$.

The seventh, eighth, and ninth experiment groups, in which $50 \mathrm{~V}$ was applied, showed a significant difference from the $35 \mathrm{~V}$ test group $[F(2-6)=1,488 \mathrm{E} 3000, p<0.01]$.
To find the source of significant difference, a Tukey HSD test was performed. Findings of experiments performed at $50 \mathrm{~V} / 10 \mathrm{~Hz}$ were determined to be significant $(p<0.01)$, but the difference between the eighth and ninth experimental groups was not significant $(p>0.01)$.

With comparison of the $1.25 \mathrm{~Hz}$ frequency values of different voltages $(20 \mathrm{~V}, 35 \mathrm{~V}$ and $50 \mathrm{~V})$, significant between-group differences were found $[F(2-6)=7,000$, $p<0.05]$. To find the source of significant difference, a Tukey HSD test was performed. The difference was significant between $20 \mathrm{~V} / 1.25 \mathrm{~Hz}$ ) and $50 \mathrm{~V} / 1.25 \mathrm{~Hz}$ $(p<0.05)$.

With comparison of the $2.5 \mathrm{~Hz}$ frequency values of different voltages $(20 \mathrm{~V}, 35 \mathrm{~V}$, and $50 \mathrm{~V})$, no significant between-group differences were found $[F(2-6)=2,600$, $p>0.05]$.

With comparison of the $10 \mathrm{~Hz}$ frequency values of different voltages $(20 \mathrm{~V}, 35 \mathrm{~V}$ and $50 \mathrm{~V})$, the betweengroup differences were significant $[F(2-6)=798,250$, $p<0.05]$. To find the source of significant difference, a Tukey HSD test was performed. Between the findings of the experiments performed at $50 \mathrm{~V} / 10 \mathrm{~Hz}$ and $20 \mathrm{~V} / 10 \mathrm{~Hz}$, the difference from $35 \mathrm{~V} / 10 \mathrm{~Hz}$ was determined to be significant $(p<0.05)$. The negative effect of the $50 \mathrm{~V} / 10 \mathrm{~Hz}$ voltage and frequency prevents us from using this electric barrier system for fish.

\section{Discussion and conclusion}

Water flow occurs toward the water pump during the withdrawal of water for irrigation or drinking. In this study, an electric fish barrier was designed to keep fish away from electric pumps during these withdrawal 
periods. The tested electric fish barrier system, confirmed under laboratory conditions, will prevent fishes from escaping into irrigation canals and stop damage to the water pump caused by the presence of fish.

Electric fish barriers are more effective and more dangerous than other fish barrier system. Current has been applied to the system in the form of a square wave to reduce the damage to the human and other creatures. Thus, the fish can move away from the territory without being captured to electric current. Area must be surrounded by a fence for living creature not to reach. The warning signs must be placed to the area for humans.

A total of 2,642 million fry were drawn away by Eğirdir Lake pump stations in 2010. 2.535 million of these are goby fish (N. caucasica), 89,450 are carp, 9978 are catfish (Nemacheilus sp.), and 6734 are crab (P. potamios). Fish that died in the output channels of irrigation pumps were broken down by proportion as follows: small goby, 95.98\%; carp, 3.39\%; scavenger, $0.38 \%$ (Uysal and Bolat, 2010). While the fish species that died or passed into the irrigation canal do not have economic importance in and of themselves, these fish feed the lake's important carnivorous fish. This study should therefore positively contribute to the regional economy.

A bubble fish barrier in another study was carried out under the same laboratory conditions. $12.9 \%$ of the fishes passed through the bubble barrier system. In the electric fish barrier system, $3.3 \%$ of the fishes passed through barrier when the barrier was operated at the optimal on fish, $20 \mathrm{~V} / 10 \mathrm{~Hz}$ and $35 \mathrm{~V} / 10 \mathrm{~Hz}$ can be used. The barrier's application depth, the physical conditions of the region, temperature, salinity, conductivity, fish species, and fish size values each have an impact on the effectiveness of the barrier, voltage and frequency. Therefore, the electric barrier system was more effective than the bubble barrier system. Statistical analysis and findings demonstrated that $50 \mathrm{~V} / 10 \mathrm{~Hz}$ cannot be used for the barrier due to its negative effect.

\section{References}

[1] Hutson, R. B. Alman Elektrikli Balık Ağı, // Balıkve Balıkçılık Dergisi. 1, 9(1953), pp. 13-16.

[2] Smith, E. D. Electric shark barrier: initial trials and prospects. // Power Engineering Journal. 5, 4(1991), pp. 167-176. https://doi.org/10.1049/pe:19910036

[3] Kolz, A. L.; Johnson R. E. In-Water electroshock Techniques to Repel Aquatic Mammals and Birds. // National Wildlife Research Center Repellents Conference 1995, pp. 203-215.

[4] Mcinerney, M. K.; Bushman, J. B.; Abdallah, T.; Nielsen, P. H.; Lilly, T. G.; Shea, C. B.; Hock, V. F.; Britt, J. T. Electrical Effects on Barges, Tows and People by The Chicago Sanitary And Ship Canal Electric Fish Barrier: Preliminary Results. // 2005 IEEE Symposium on Product Safety Engineering, pp. 54-64, 2005. https//doi.org/10.1109/PSES.2005.1529523

[5] Lambooij, E.; Kloosterboer, R. J.; Gerritzen, M. A.; Van de Vis, J. W. Assessment of electrical stunning in fresh water of African Catfish (Clariasgariepinus) and chilling in ice water for loss of consciousness and sensibility. // Aquaculture, 254, 1-4(2006), pp. 388-395. https://doi.org/10.1016/j.aquaculture.2005.10.027

[6] Huveneers, C.; Rogers, P. J.; Semmens, J.; Beckmann, C.; Kock, A. A.; Page, B.; Goldsworthy, S. Effects of the Shark Shield ${ }^{\mathrm{TM}}$ electric deterrent on the behaviour of white sharks (Carcharodoncarcharias). Final Report to Safe Work South Australia. // South Australian Research and Development Institute (Aquatic Sciences), Adelaide. SARDI Publication No. F2012/000123-1. SARDI Research Report Series No. 632. (2012), 61 pp.

[7] Erikson, U.; Lambooij, B.; Digre, H.; Reimert, H. G. M.; Bondø, M.; Vandervis, H. Conditions for instant electrical stunning of farmed Atlantic cod after de-watering, maintenance of unconsciousness, effects of stress, and fillet quality-A comparison with AQUI-STM. // Aquaculture. 324-325(2012), pp. 135-144. https://doi.org/10.1016/j.aquaculture.2011.10.011

[8] Franssen, N. R.; Davis, J. E.; Ryden, D. W.; Gido, K. B. Fish community responses to mechanical removal of nonnative fishes in a large southwestern river. // Fisheries. $41,8(2014)$, pp. $352-363$. https:// doi.org/10.1080/03632415.2014.924409

[9] Parker, A. D.; Glover, D. C.; Finney, S. T.; Rogers, P. B.; Stewart, J. G.; Simmonds, R. L. Direct observations of fish incapacitation rates at a large electrical fish barrier in the Chicago Sanitary and Ship Canal. // Journal of Great Lakes Research. 41, 2(2015). pp. 396-404. https://doi.org/10.1016/j.jglr.2015.03.004

[10] Smith Root INC. Fish Barriers \& Guidance. 2013 http://www.smith-root.com/images/smithroot/downloads/ 57/09446.004_barrier_book.pdf (05.10.2014)

[11] Electrical Fields. Fish and Wildlife Service, 2011. http://training.fws.gov/EC/Resources/ElectrofishingResou rces/ManualChapters/Chapter3.pdf (16.10.2014)

[12] LM2576HV-ADJ. Texas Instruments. 2013. http://www.ti.com/product/lm2576hv (18.10.2014)

[13] Hiticas, I.; Marin, D.; Mihon, L. Modelling and operational testing of pulse-width modulation at injection time for a spark-ignition engine. // Tehnicki vjesnik/Technical Gazette. 20, 1(2013), pp. 147-153.

\section{Authors' addresses}

Talat Yalçınkaya, Lecturer

Mehmet Akif Ersoy University, Burdur, Turkey

talatyk@mehmetakif.edu.tr

Abdülkadir Çakır, Associate Prof.

Suleyman Demirel University, Isparta Turkey abdulkadircakir@sdu.edu.tr

Yildzz Bolat, Associate Prof.

Suleyman Demirel University, Isparta Turkey yıldızbolat@sdu.edu.tr

\section{Rahmi Uysal, Researche}

Eğirdir Fisheries Research Station, Eğirdir, Isparta, Turkey uysalrahmi@hotmail.com

Ali Aslantas, Ph.D

Mehmet Akif Ersoy University, Burdur, Turkey aslantas@mehmetakif.edu.tr 